\title{
PHOTOESSAY
}

\section{Manus to Meanjin A case study of refugee migration, polymorphic borders and Australian 'imperialism'}

\begin{abstract}
This non-traditional research article argues that the refugee and asylum-seeker protests in Brisbane's Kangaroo Point between April 2, 2020 and April 14, 2021 can be viewed against a backdrop of Australian colonialism - where successive Australian governments have used former colonies in Nauru and Manus Island in Papua New Guinea as offshore detention facilities - as a dumping ground for asylum-seeker. Within the same context this article argues that the men's removal to the Kangaroo Point Alternative Place of Detention is a continuation of this colonial policy of incarcerating 'undesirables' on occupied land, in this case on Meanjin - Jagera land identified by the colonial name of Brisbane. This extension of Australian sub-imperial and neo-colonial dominion and the imagining of its boundaries is viewed through the theoretical prism of a polymorphic border, border that shifts and morphs depending on who attempts to cross it. In a departure from orthodox research practice, this article will use visual storytelling drawn from photojournalism praxis alongside more traditional text-based research prose. In doing so, it will use photojournalistic artifacts and the visual politics that surround them, as core dialogical components in the presentation of the article as opposed to using them as mere illustrations or props.
\end{abstract}

Keywords: asylum seekers, Australia, case studies, human rights journalism, Nauru, Papua New Guinea, photojournalism, polymorphic borders, refugees, research methodologies, storytelling, visual politics, visual storytelling

\section{KASUN UBAYASIRI \\ Griffith University, Brisbane}

\section{Photojournalistic practice, research and the visual turn}

-HE CONVERSATION on refugee migration, and perhaps more poignantly its mediatisation, has largely focused on the linguistic framing of refugees, and their migration experience, within the wider space of social and political discourse-largely ignoring the visual. 
Bleiker et al. (2013) argue this media framing often sidelines visual framing in contemporary research. They argue refugees are routinely dehumanised by representing them in groups devoid of 'recognisable facial features'. They note 'these dehumanising visual patterns reinforce a politics of fear...'. Furthermore, Höijer (2004) maintains that imagery shapes perception in a way that words cannot, 'The compassion that the audience expresses is often directly related to the documentary pictures they have seen...'. She argues, 'pictures, or more precisely our interpretations of pictures, can make indelible impressions on our minds, and as a distant audience we become bearers of inner pictures of human suffering' (p. 520).

Bleiker (2015) states 'images play an increasingly important role in global politics but pose significant and so far, largely unexplored methodological challenges'. He argues that humanities scholarship is increasingly acknowledging the potential of visual elements to generate meaning, so much so that we are now moving away from purely textual analyses and placing greater emphasis on the visual.

This renewed interest in visual methodology is positioned within a wider epistemological shift, from a 'linguistic turn'- the final series of turns in the history of philosophy outlined by the American philosopher Richard Rorty- to a 'visual turn' or what University of Chicago professor of art W.J.T. Mitchell (1995) dubbed a 'pictorial turn', the idea that challenges language as paradigmatic for meaning. He notes:

...one might identify it with phenomenology's inquiry into imagination and visual experience; or with Derrida's 'grammatology', which de-centers the 'phonocentric' model of language by shifting attention to the visible, material traces of writing; or with the Frankfurt School's investigations of modernity, mass culture, and visual media; or with Michel Foucault's insistence on a history and theory of power/knowledge that exposes the rift between the discursive and the 'visible', the seeable and the sayable, as the crucial faultline in 'scopic regimes' of modernity (1995, pp. 11-13).

Callahan (2015) takes this concept of a 'visual turn' and presents it as a new methodology in international relations discourse. Within a journalistic frame, it is not a stretch to assert therefore that Callahan's assertion can be taken further to argue that vision should be an equal partner in the meaning-making of transborder reportage.

Such duality of the textual and visual in meaning-making then, suggests the image can not only be studied, analysed and explained though text, but sit alongside text in the academic analysis of reality. It can then be posited, that a theorisation of the journalistic interpretation of the 'reality' of refugee migration need not be presented as a purely textual analysis, as is tradition, but through a composite of textual and visual elements. 
Positioned within a wide range of academic studies that explore journalism praxis and research (Bacon, 2006, 2012; Nash, 2013; Lindgren \& Phillips 2011; Robie, 2015; Robie \& Marbrook, 2020), this article will harness this visual dialogue within a journalistic practice-led research paradigm to explore the nexus between the refugee and asylum-seeker protests in Brisbane's Kangaroo Point and Australia's colonial past and the polymorphic borders of its neo-colonial present.

\section{Refugee migration and Australian immigration detention}

The refugee protests in Brisbane began when a group of refugees stepped out onto a balcony overlooking Route 15 to Storey Bridge on 2 April 2020, holding handwritten pleas for freedom. The protest would last from 2 April 2020 to 14 April 2021, ebbing, flowing and morphing from a balcony protest to an aroundthe-clock-blockade and variously traffic-stopping rallies and night-time vigils. But the root of the protests runs deeper, through two decades of oppressive refugee policies to a bedrock of what Australian historian Humphrey McQueen (2004) calls Australia's sub-imperialist mindset.

Most of the 120 men locked up in the Kangaroo Point Alternative Place of Detention, sought asylum in Australia after the second Rudd government took the hardline position of refusing to settle any asylum seekers coming to Australia by boat. Some missed the deadline by mere days, others were already at sea when the Prime Ministerial edict was issued. With their boats intercepted, the asylum seekers were first sent to the Australian external territory of Christmas Island and from there to Nauru and Papua New Guinea's Manus Island. The result was eight agonising years of immigration purgatory.

But the government had good reason to believe the position was both popularly supported and politically advantageous. Markus and Arunachalam note '... while there is majority support for the right to seek asylum, in response to questions on boat arrivals strong negative views outnumber the strong positive by more than two to one' (2018). The Lowy Institute's Munro and Oliver (2019) noted '(i)n 2018, large numbers of immigrants and refugees coming into Australia' was seen as a critical threat by 40 percent of Australians, essentially unchanged from the previous time the question had been asked in 2009 when it was 39 percent'. Studies of public attitudes towards people seeking asylum in Australia suggest they are often labelled as 'illegal immigrants', 'queue jumpers', 'bogus' refugees and 'economic migrants' (Gelber, 2003; Every \& Augoustinos, 2008; Laughland-Booÿ et al., 2014; McKay et al., 2012).

While media representation is not exclusively responsible for public opinion of refugee migration, a significant number of studies show public perceptions are shaped though media coverage (McKay, 2012). These negative perspectives are mirrored in the media coverage where the portrayal is either overwhelmingly negative (Bleiker et al., 2013, O’Doherty and Lecouteur 2007; Pickering 2001, 
Saxton, 2003), or polarised (Lippi, 2020). These narratives while negative, are also rather limiting in contextualising refugee migration both within the reality and complexities of trans-border migration and the wider geo-politics of imagining, nations, sovereignty, 'us' and 'them'.

Within the Australian context this identity formation, the inclusion, exclusion and even the presentation of offshore detention as a solution, can be viewed through what McQueen (2004) calls Australia's sub-imperialism.

Cognisant of this wider framing and the limited depth of analytical reportage of refugee migration in the mainstream media, this article posits a photojournalism-centric visual storytelling methodology, is able to produce a counterhegemonic narrative of refugee migration, situating Australia's treatment of refugees within largely subterranean colonial and neo-colonial thinking that has prevailed throughout much of Australia's history. It also argues the media framing of refugee migration needs to be represented as a transborder issue across multiple polymorphic borders, challenging the Australian government's hegemonic representation of the border as an omnipotent and uniform structure perfectly defining the edges of Australia.

\section{Kangaroo Point protests}

On 13 July 2019, Prime Minister Kevin Rudd declared that no asylum seeker arriving by boat would be settled in Australia. From this point on, those people would be referred to as 'transitory persons', and their stay would be considered by the government to be temporary. Who exactly this affected is difficult to ascertain as demographic data on refugees and asylum seekers in Australia's various detention centres is not easily accessible and even at a political level there is often little transparency, with only select data released through avenues such as Senate Estimates hearings. For example, in response to a question from Greens Senator Nick McKim, the Immigration and Border Protection Portfolio noted on 29 March 2017, that

(B)etween 19 July 2013 and the last boat arrival on 27 July 2014, 79 boats arrived in Australia. There has not been a boat arrival in more than 950 days. Of the individuals on board, 1,596 were transferred to the Nauru Regional Processing Centre, 1,523 were transferred to the Manus Regional Processing Centre and 1,414 were issued with bridging visas in Australia.

The decision to grant bridging visas for some and not others was explained away as the Minister exercising his 'non-delegable personal power'. The process remains opaque, and the resultant statistics are stripped of even the most basic of humanising, demographic information. This bureaucratic dehumanisation is reflected in the lived experiences of the asylum seekers themselves.

An Iranian refugee who was sent from Christmas Island to Manus and from 
there to Kangaroo Point said 'the Australian government did everything they could not to refer to us as refugees or asylum seekers. I was "a client" in Christmas Island, "the transferee" on Manus Island, "a resident" after the Supreme Court ruling, and a "detainee" at Kangaroo Point'. The ruling refers to the 2016 PNG Supreme Court decision that declared the detention of asylum seekers on Manus Island, under arrangement with Australia, a breach of the refugees' right to personal liberty under the Papua New Guinea Constitution.

Most of the men in offshore detention were eventually acknowledged as official refugees. But the conservative Liberal governments of Abbott, Turnbull and Morrison continued their Labor predecessor's policy and have refused to settle even those with official refugee status. Instead, they have been offered ongoing limbo or an excruciatingly slow settlement process in the US under a deal to swap Australian refugees with US refugees.

Nonetheless, the Australian government still had responsibility for the detainees, which included provision of medical care. However, lengthy delays in the medical evacuation regime, led to calls for a new framework, paving the way for Independent MP Dr Kerryn Phelps to introduce the Medevac Bill to parliament. On 1 March 2019, Medevac became law authorising doctors to make medical rulings to evacuate refugees and asylum seekers detained on Manus and Nauru to Australia for urgent medical treatment. By the time the Law was repealed on 8 December 2019, 192 detainees had been evacuated under the legislation (Kaldor Centre, 2020). The problem was, the refugees who had been transferred to Australia for medical treatment had not been granted a visa authorising entry, so they were placed in detention - primarily at the Kangaroo Point APoD, and Melbourne's Park Hotel APoD.

And so it was that 120 Medevac refugees were locked in at the Kangaroo Point APoD when Queensland entered a hard COVID lockdown on April 2, 2020.

\section{Offshore detention and Australia's sub-imperialism:}

In his provocative analysis of Australia's birth as a nation, A New Britannia, McQueen (2004) argues that for much of Australia's history, the colonists who occupied the continent as an outpost of the British Empire have in return, viewed the neighbouring Pacific region though Australia's own version of a 'Monroe Doctrine', exhibiting sub-imperial tendencies first as a group of prefederation British colonies and later as federated neo-colonialists-where the colonial dominion of the Pacific shifted from Britain to Australia.

Tod Moore's (2015) study of liberal imperialist thought in Australia as expressed though the Imperial Federation League and the friends and associates of Protectionist and later Liberal Party Prime Minister Alfred Deakin, presents an image of an Australia imagining itself as member of federated empire. Thompson's (1972) critique of the Australian Labor Party and Australian imperialism suggest similar sentiments 


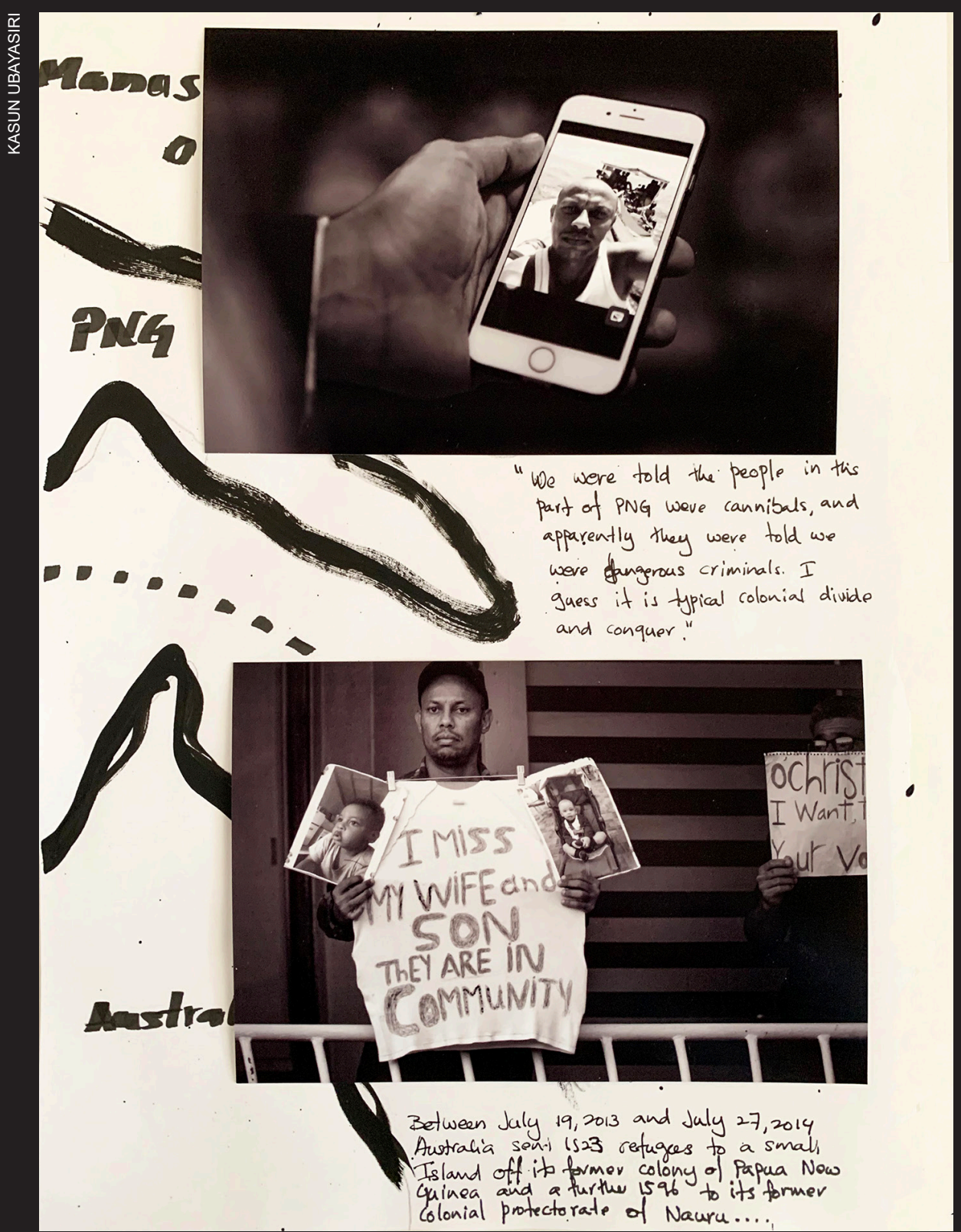

Figure 1: 'I miss my wife and son. They are in community.' 


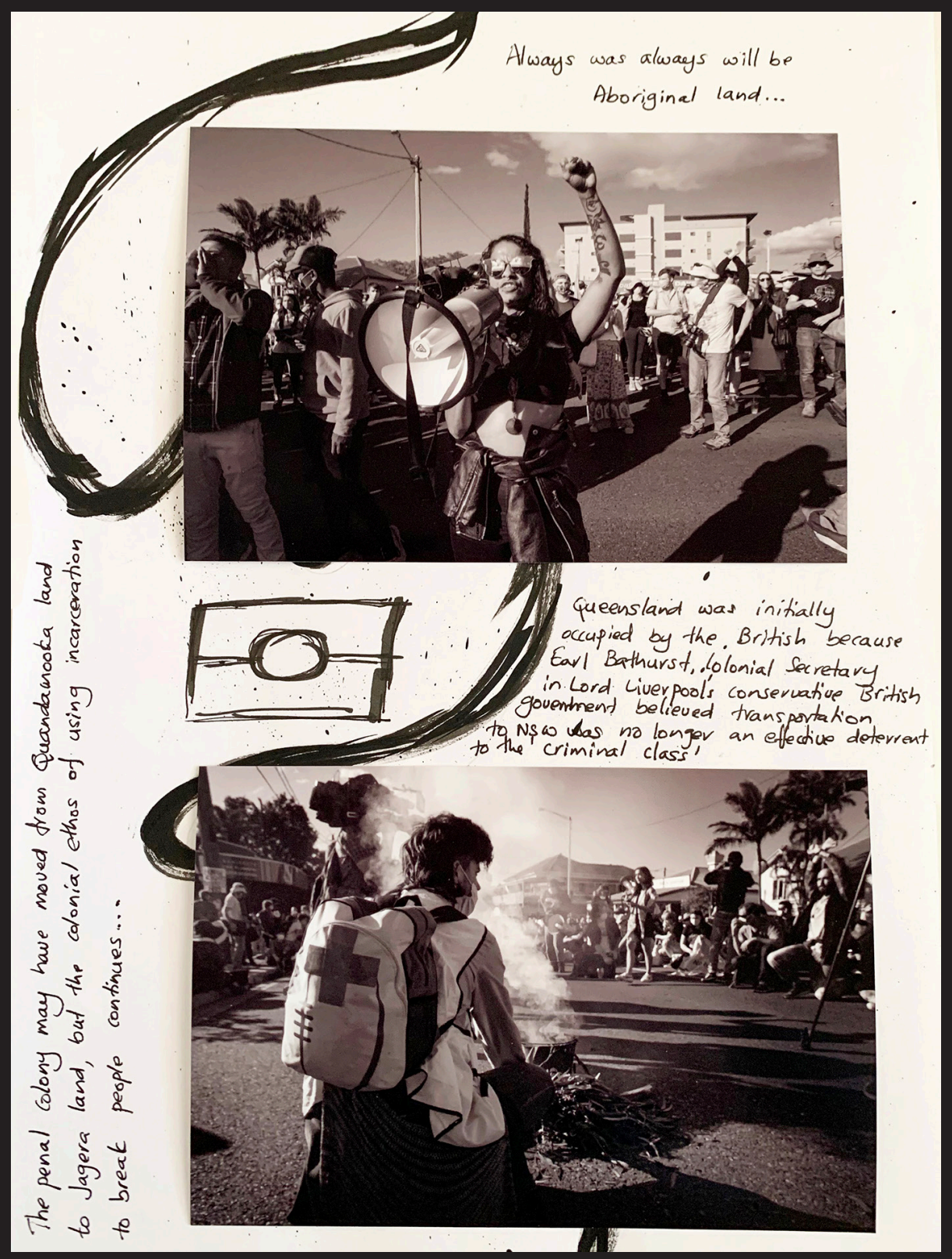

Figure 2: 'Always was always will be Aboriginal land ...' 
on the other side of the political divide, albeit with some xenophobic reservations. He notes that while the Victorian Labor party organ The Tocsin feared imperialism would only benefit a few 'fatmen', Brisbane's The Worker and Sydney's The Australian Worker feared the implications of access to a cheap 'black' workforce - and warned against the threat of "black New Guinean labour sullying the purity of white Australia' (Thompson, 1972, p. 27).

Labor's xenophobia against the New Guineans, however, did not temper Australia's or (prior to federation) Queensland's sub-imperial designs on Papua New Guinea. As far back as 1883 Queensland pastoralist Premier Thomas McIlwraith had unilaterally attempted to annex eastern New Guinea to Queensland by raising the British flag in Port Moresby (Jacobs, 1952, p111; McQueen, 2004, p. 15); and by 1919, a now federated Australia formally annexed New Guinea under the Treaty of Versailles. In short, the Australian policy of sub-imperialism centred around securing dominion over New Guinea, while maintaining the ethnic purity of White Australia (O'Brien, 2009).

The Australian colonisation of Nauru runs along similar lines to that of its colonisation of Papua New Guinea, the only difference being New Zealand's sub-imperialism joining forces with Australian and British dominion of the tiny phosphorous-rich Pacific nation.

While Papua New Guinea was granted independence from Australia in 1975 under the Whitlam government, many analysts argue the 'master-servant' relationship continued long after independence (Ritchie, 2013).

Australian foreign aid - official development assistance as a percentage of gross national income - has been steadily declining for decades. Development Policy Institute's Robin Davies (2017) notes that Australia's highest ratio of aid to Gross National Income (GNI) was 0.48 percent under Prime Ministers Holt, McEwen and Gorton. Davies' argues, the much-publicised figure of 0.65 percent under Whitlam is based on inaccurate OECD data. Either way Australian aid as a percentage of GNI has today reached an all-time low-just 0.24 percent under John Howard between 2000-04, and even lower under the Abbot-Turnbull government at 0.22 percent in 2016. Aid further fell to a record low of 0.21 percent under Morrison in 2019-20, and while it marginally recovered in the following financial year, creeping up to 0.22 percent, it is estimated to dip below 0.20 percent in 2022-23.

Despite this downward trajectory of foreign aid, Australia's Official Development Assistance (ODA) to Papua New Guinea and the Pacific specifically have remained largely unchanged, with PNG becoming the largest recipient of Australian Aid in 2015-16 (Lowey Institute, 2016). While aid is most welcome and needed in the region, the 'pork barrelling' is seen by some analysts as an extension of Australian neo-colonialism, where aid is provided in exchange for PNG's role in allowing the redirection and detention of people seeking asylum in Australia. 
This complex asymmetric partnership with Nauru and Papua New Guinea is central in framing and mediating the political reality of contemporary refugee migration, where Australia continues to use its former colonies in the Pacific, now tethered though the promise of ongoing foreign aid, as a buffer against irregular refugee migration into Australia.

\title{
Polymorphic borders
}

The selective immigration that has long been a hallmark of a white Australian immigration policy may no longer be as aggressive as it used to be, but it is nearly impossible to view Australia's response to irregular migration without reference to a culture of immigration discrimination. The visual representation of such an idea is intrinsically linked with the notion of understanding national borders as polymorphic, in that they not only are porous to some and impervious to others, but also shift and morph depending on who tries to cross.

Parochial political posturing has long tried to embed the notion of a robust and continuous border circling the continent, but the reality is there is no singular line to cross or marker buoy to pass to enter Australia - it remains contextual. A sailor entering Australian waters on luxury yacht can legally land on Queensland's northern beaches and be, for all intents and purposes, in Australia. Yet thanks to a 16 May 2013 legal device that excised virtually all of Australia's shoreline from the mainland for irregular migration purposes - a refugee arrival by boat landing on the same beach will never be considered to have set down in Australia

In their introduction to Territory, Politics and Governance's special issue on Polymorphic Borders, Burridge et al. (2017) say contemporary border studies describe state borders to be far more fragmented and chaotic than represented in traditional narrative of state borders whereby they are often defined as 'coherent, monstrous, omnipotent and omniscient', and are fixed and immovable. They write:

\begin{abstract}
Rather than being either strictly tied to the territorial margins of the states or ubiquitous throughout the entire territory of states, bordering takes on a variety of forms, agents, sites, practices and targets. We propose reconceptualising borders as polymorphic, or taking on a multiplicity of mutually non-exclusive forms at the same time. $(2017$, p. 239)
\end{abstract}

Such a concept of borders is particularly relevant in the mediated representation of the refugee crisis - where the men on the balcony physically standing inside a suburban hotel in Brisbane, Australia, are in many ways still positioned outside of Australia, somewhere in limbo between their last location on Manus Island in Papua New Guinea and their next destination which remains as of yet unknown. This reimaging of the nature of borders is also significant in understanding and challenging the 'stronger borders' rhetoric of successive Australian governments. 


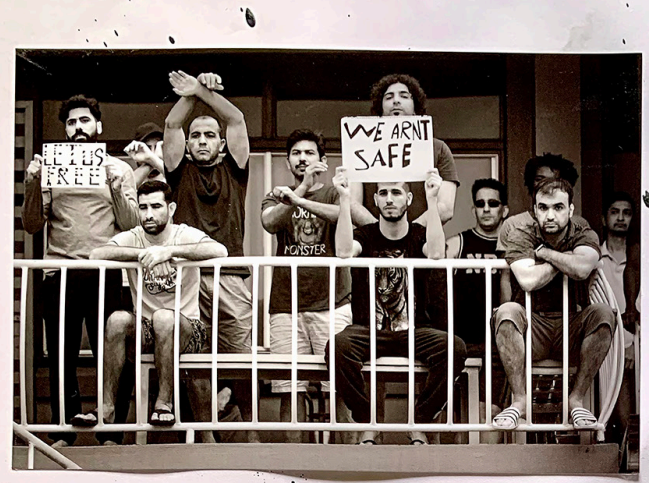

The Australian border, like its colonial Dominion is anytting bat uniform...

- The Australian border for asylum-seekous coming by boat: Australiás outer Islands - Ashmore, Cartier, Chnstumas and Cocos continue to be part of Aust. territory bat coutside its migration rone..

on May 16,2013 the labor gout excised the entire main - land from the Aust

migration zome to people coming by

The Australian Border for Asseykem-seekers coming by Plane:

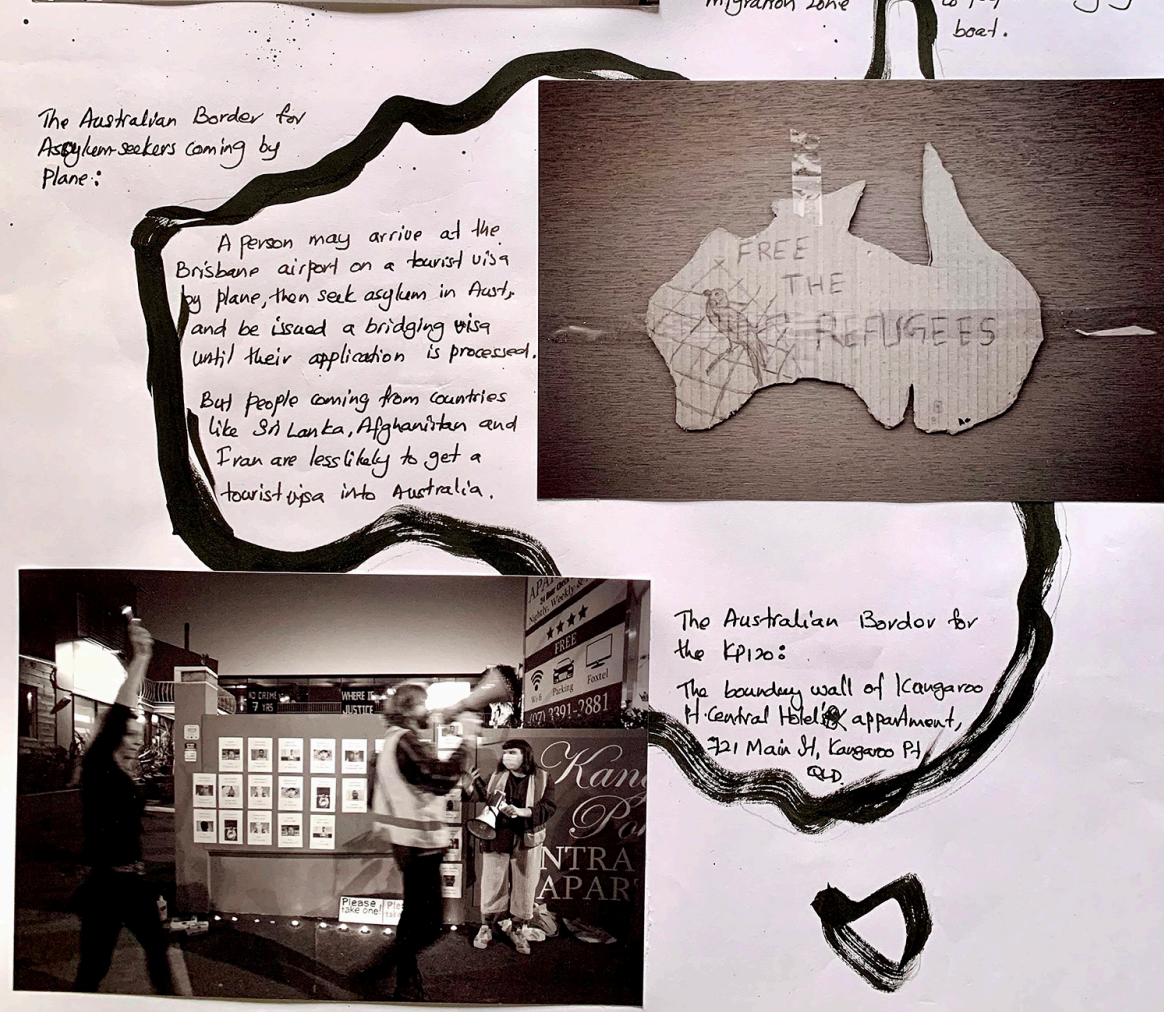

Figure 3: 'The Australian border, like its dominion, is anything but uniform.' 


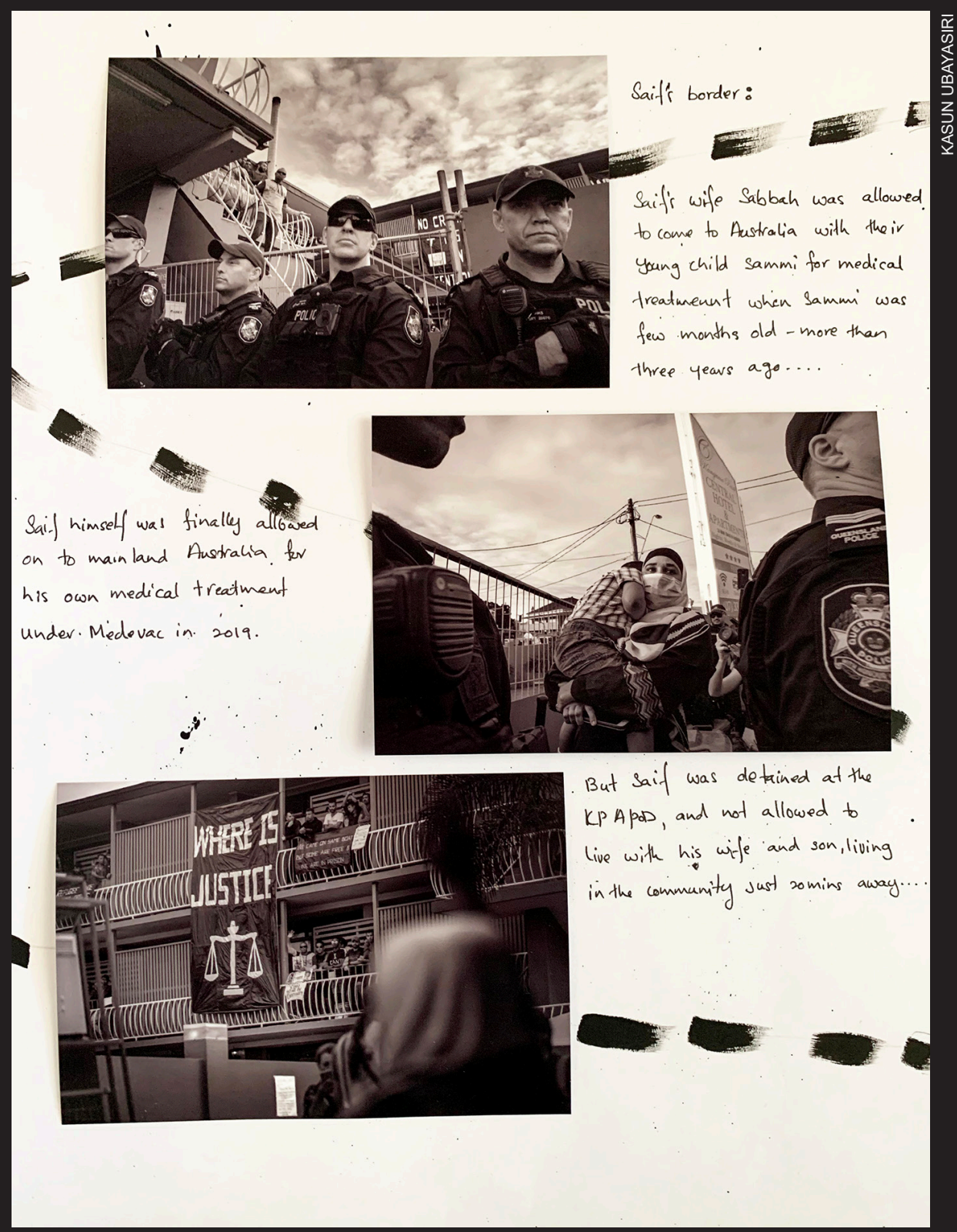

Figure 4: 'Saif's border: where is justice?' 


\section{Conclusion}

The mediatised representation of the refugee migration reality in Australia can be situated within two interlocking meta-narratives, that of Australia's sub-imperialism and neo-colonialism, and the polymorphic nature of the border that it creates. Such a narrative challenges the political media hegemony of a strong border which is unified and omnipotent, instead of one that is largely contextual and conditional upon who tries to cross it.

The reach of Australia's new colonial dominion and the nature of its polymorphic border within that context is central in understanding the mediated reality of refugee migration in general, and the story of refugees who were detained at the Kangaroo Point Alternative Place of Detention in particular. Such a reading positions Brisbane's refugee protest as a localised border-war wherein the walls and wire of the hotel complex is an extension of the Australian border which is porous for some but impervious to others. The war wages between those with unfettered access, those trapped behind and collaborators escaping their own lockdowns to show solidarity.

The interplay between text and images in allows for a more comprehensive narrative of this reality that negotiates between the micro and macro elements of the narrative where the macro conceptualisation of refugee migration with in Australia's neo-colonial setting can simultaneously incorporate the micro narratives that humanise individual refugees.

\section{References:}

Australian Council for International Development. (2020). 2020-2021 Development Budget: Facts and Figures. Retrieved from https://acfid.asn.au/sites/site.acfid/ files/ACFID $\% 202020-2021 \% 20$ Budget $\% 20$ Analysis $\% 20 \% 281 \% 29$.pdf?mc_ $\mathrm{cid}=28580 \mathrm{bfb} 84 \& \mathrm{mc}$ eid $=2 \mathrm{e} 8 \mathrm{a} 0 \mathrm{c} 4 \mathrm{f} 50$

Bacon, W. (2006). Journalism as research? Australian Journalism Review, 28(2), 147-157.

Bacon, W. (2012). FRONTLINE: An innovative direction in academic journalism. Pacific Journalism Review : Te Koakoa, 18(2), 153-165. https://doi.org/10.24135/ pjr.v18i2.270

Bleiker, R. (2015). Pluralist methods for visual global politics. Millennium, 43(3), 872890. https://doi.org/10.1080/10361146.2013.840769

Bleiker, R., Campbell, D., Hutchison, E., \& Nicholson, X. (2013). The visual dehumanisation of refugees. Australian Journal of Political Science, 48(4), 398-416. https://10.0.4.56/10361146.2013.840769

Burridge, A., Gill, N., Kocher, A., \& Martin, L. (2017). Polymorphic borders. Territory, Politics and Governance, 5(3), 239-251. https://doi.org/10.1080/21622671.2017.12 97253

Callahan, WA. (2015). The visual turn in IR: Documentary filmmaking as a critical method. Millennium, 43(3), 891-910. https:// doi.org/10.1177/0305829815578767

Davies, R. (2017, February). Measuring Australia 's foreign aid generosity, from Menzies to Turnbull. Development Policy Centre: policy brief 16. Retrieved from https://devpolicy. 
org/publications/policy_briefs/PB16\%20Measuring\%20Australia\%E2\%80\%99s $\% 20$ foreign $\% 20$ aid $\% 20$ generosity.pdf

Every, D., \& Augoustinos, M. (2008). Constructions of Australia in pro-and anti-asylum seeker political discourse. Nations and Nationalism, 14(3), 562-580. https://doi. org/10.1111/j.1469-8129.2008.00356.x

Gelber, K. 2003. A fair queue? Australian public discourse on refugees and immigration. Journal of Australian Studies, 27(77), 23-36. https://doi. org/10.1080/14443050309387848

Höijer, B. (2004). The discourse of global compassion: The audience and media reporting of human suffering. Media, Culture \& Society, 26(4), 513-531. https://doi. org/10.1177/0163443704044215

Jacobs, M. G. (1952). The colonial office and New Guinea, 1874-84. Australian Historical Studies, 5(18), 106-118.

Kaldor Centre, (2020). Medical transfer from offshore processing to Australia. University of New South Wales (Sydney). Retrieved from https://www.kaldorcentre.unsw.edu. $\mathrm{au} /$ sites/kaldorcentre.unsw.edu.au/files/Factsheet_Medical_Transfers.pdf

Laughland-Booy, J., Skrbis, Z., \& Tranter, B. (2014). Toleration or trust?: Investigating the acceptance of 'boat people' among young Australians. The Australian Journal of Social Issues, 49(2), 195-217. https://doi.org/10.1002/j.1839-4655.2014.tb00308.x

Lindgren, M., \& Phillips, G. (2011). Conceptualising journalism as research: Two paradigms. Australian Journalism Review, 33(2), 73-83.

Lippi, K., McKay, F. H., \& McKenzie, H. J. (2020). Representations of refugees and asylum seekers during the 2013 federal election. Journalism, 21(11), 1611-1629. https://doi.org/10.1177/1464884917734079

Lowy Institute (2016). Australian Foreign Aid. Retrieved from https://www.lowyinstitute. org/issues/australian-foreign-aid

Markus, A., \& Arunachalam, D. (2018). Australian public opinion on asylum. Migration and Development, 7(3), 435-447.

McKay, F. H., Thomas, S. L., \& Kneebone, S. (2012). 'It would be okay if they came through the proper channels': Community perceptions and attitudes toward asylum seekers in Australia. Journal of Refugee Studies, 25(1), 113-133. https://doi. org $/ 10.1093 / \mathrm{jrs} /$ fer010

McQueen, H. (2004). A new Britannia. St. Lucia, Qld: University of Queensland Press.

Mitchell, W.J.T. (1995). Picture theory. Chicago, IL: University of Chicago Press.

Moore, T. (2015). Liberal imperialism in Australian political thought, 1902-14. The Journal of Imperial and Commonwealth History, 43(1), 58-79. https://doi.org/10.10 $80 / 03086534.2014 .941167$

Munro, K \& Oliver, A (2019). Polls apart: how Australian views have changed on 'boat people'. Lowy Institute. Retrieved from https://www.lowyinstitute.org/the-interpreter/ polls-apart-how-australian-views-have-changed-on-boat-people

Nash, C. (2013). FRONTLINE: Journalism as a research discipline. Pacific Journalism Review : Te Koakoa, 19(2), 123-135. https://doi.org/10.24135/pjr.v19i2.221

O'Brien, P. (2009). Remaking Australia's colonial culture?: White Australia and its Papuan frontier 1901-1940. Australian Historical Studies, 40(1), 96-112.

O'Doherty, K. \& Lecouteur, A. (2007) 'Asylum seekers', 'boat people' and 'illegal immigrants': social categorisation in the media. Australian Journal of Psychology, 59(1), 1-12. https://doi.org/10.1080/00049530600941685

Pickering, S. (2001). Common sense and original deviancy: News discourses and asylum seekers in Australia. Journal of Refugee Studies, 14(2), 169-186. https://doi. 
org/10.1093/jrs/14.2.169

Ritchie, J. (2013, July 25). Colonialism, sovereignty and aid: what refugees mean for PNG. The Conversation. https://theconversation.com/colonialism-sovereigntyand-aid-what-refugees-mean-for-png-16318

Robie, D. (2015) Advocating journalism practice-as-research: A case for recognition in the New Zealand PBRF context. Asia Pacific Media Educator, 25(1), 62-73. https:// doi.org/10.1177/1326365X15575591

Robie, D., \& Marbrook J. (2020). Bearing witness: A Pacific climate crisis documentary and journalism development project. Asia Pacific Media Educator, 30(1), 77-91. https://doi.org/10.1177/1326365X20945417

Saxton, A. (2003). 'I certainly don't want people like that here': The discursive construction of 'asylum seekers'. Media International Australia, 109(1), 109-120. https://doi. org/10.1177/1329878X0310900111

Thompson, R. C. (1972). The Labor Party and Australian Imperialism in the Pacific, 1901-1919. Labour History, 23, 27-37.

Dr Kasun Ubayasiri is the programme director of the Bachelor of Journalism programme at Griffith University, Queensland, Australia. He is a former Sri Lankan journalist and a journalism researcher specialising in the role of human rightsbased journalism in armed conflict. He is a member of the Griffith Centre for Social and Cultural Research (GCSCR), and co-author of Journalism for Social Change in Asia: Reporting Human Rights (2017).

k.ubayasiri@griffith.edu.au 